\title{
THE PRINCIPLE OF LEGALITY AS A FOUNDATION OF MODERN CIVIL SOCIETY
}

\section{Alina Murtishcheva}

\section{INTRODUCTION}

Constitutional reform had profound political and legal consequences for Ukraine as a country trying to construct law-based state and to establish rule of law. Such state should declare the separation of state authority, the legal character of government, the legal protection of citizens from violations of their rights by state power, compensation for damage caused to them by state bodies.

The establishment of legal statehood and the practical implementation of the principle of the rule of law require the strict observance of the constitution and laws, first of all by public authorities and their officials. This is especially significant to the executive authority. The rule of law provides the basis for control over governmental actions, demanding from them to comply with the requirements of good governance. The experience of these bodies functioning demonstrates a constant tendency to increase power. Moreover, the examples of violations of the rules of the Basic Law by the power institutions have demonstrated the inability of some constitutional and legal institutions to effective regulation of public relations. That is why the issue of legal means, protecting constitutional legality, is of current importance.

In order ensure the rule of law and law-based state, there must be institutions that provide a restrictive connection between public authorities. Such restrictive institutions ensure the functioning of state authorities based on the division of power and constitutional legality. This is of significant importance for ensuring human and civil rights, as well as the implementation of the restrictive function of the constitution. Moreover, such institutions improve legal culture of officials, making a great impact on the development of civil society in general, because such society needs cooperation between citizens, non-government organizations and law-based and effective government.

\section{The notion of constitutional legality}

Researchers associate the emergence of legality with the rise of first bourgeois states in VII - VIII centuries, when legality became the principle of social and political system. The second reason was the adoption of constitutions, as it is considered that it is possible to talk about constitutional 
legality only if part of legality got its constitutional framework. Today, the principle of legality, traditionally considered a fundamental element of the rule of law, is known to the doctrines of the constitutional law of the English, French, German-speaking EU Member States (principle of legality, legalitätsprinzip, principe de la légalité), but there can be emphasis on various characteristics of the principle of legality.

For a general description of the principle of legality, one of the most respected researchers in the field of legal culture and justice professor Susan S. Silbey can be cited: "We use the word "legality" to refer to the meaning, sources of authority, and cultural practices that are recognized as legal, regardless of who employs them or for what ends. "Legality" is an analytic term rather than a socially approved state of affairs. In this rending, people may invoke and enact legality neither approved nor acknowledged by law".

Rather remarkable interpretation of the principle of legality is provided by the British doctrine and constitutional law of the Anglo-Saxon legal system countries. In general, British researchers make the point that the principle of legality states that the law should be clear, ascertainable and nonretrospective ${ }^{1}$.

Besides, the legality as principle is considered in broad and narrow terms. In a broad sense, the principle of legality means a broad set of constitutional regulations requiring that every power should be exercised only on the basis of a positive resolution ${ }^{2}$. In narrow sense of the principle of legality means a "clear statement principle" - a legislative body must speak unambiguously if it wants to compromise liberty ${ }^{3}$. Moreover "the courts should be slow to impute to Parliament an intention to override established rights and principles where that is not clearly spelt out"4. This requirement is often called minimalist, because "it left undecided the larger questions about the meaning of the Constitution". At the same time this principle protects human rights, because in the absence of clear prescriptions of the law, the courts will not

${ }^{1}$ The Government and the Principle of Legality. URL: https://www.lawteacher.net/free-lawessays/administrative-law/the-government-and-the-principle-of-legality-administrative-lawessay.php\#ftn9

${ }^{2}$ Lim B. (2013) The Normativity of the Principle of Legality. Melbourne University Law Review, Vol. 37:372. P. 373.

${ }^{3}$ Sunstein C. R. (2005) Radicals in Robes: why extreme right-wing courts are wrong for America, New York: Basic Books. P. 132.

${ }^{4}$ Sales P. (2008) A comparison of the principle of legality and section 3 of the Human Rights Act 1998. Statute law society conference. Belfast. URL: http://www.statutelawsociety.co.uk/wpcontent/uploads/2014/01/A_comparison_of_the_principle_of_legality_and_section_3_of_the_Hu man_Rights_Act_1998._Mr_Justice_Sales.pdf

${ }^{5}$ Sunstein C. R. (2005) Radicals in Robes: why extreme right-wing courts are wrong for America, New York: Basic Books. P. 132. 
impute to the legislator the intention to limit the fundamental rights established by common law. And the law must be interpreted in such a way as to minimize interference with the sphere of rights. All things considered, this approach focuses on the importance of the principle of legality for respect for human rights and freedoms.

The modern science of constitutional law in the United Kingdom discuss the question of limiting the principle of parliamentary sovereignty by the principle of legality as a constituent of the rule of law. For example, Trevor R.S. Allan, a professor at the University of Cambridge Law School, said that formally, the doctrine of absolute parliamentary sovereignty not only sanctions restrictions on constitutional rights but can theoretically abolish any requirement of the rule of law. In practice, the courts, while protecting fundamental rights, interpret the legislation and allow the limitation of parliamentary legislative supremacy. However, it is believed that "any limitation of the doctrine of legislative supremacy, necessary to sustain the rule of law, is, therefore, already implicit in the concepts of law and legality on which the "unwritten" Constitution of Great Britain is constructed. In short, no new "qualification" (or judicial amendment) of existing constitutional law is needed ${ }^{6}$. It can be concluded that the principle of constitutional legality has the potential of limiting the power by law, and the judicial branch is used as an instrument of such restriction, as will be discussed later.

Consideration of the levels of application of the principle of legality can be regarded as the achievement of the German constitutionalists. For example, Professor Anne Peters noted that the principle of legality (German, gesetzmäßigkeit) today is developed at two "levels" of law (domestic and international). So this principle can be interpreted as a multi-level, transnational or global principle. The basic nature (material importance) of the principle of legality confirms its characteristic as belonging to a global constitutional law ${ }^{7}$.

Austrian constitutional law has rather unique and interesting look at the significance of the principles of constitutional law in general. For example, according to Professor Theo Öhlinger's opinion, constitutional law is bimodal: its basic principles are understood as "super-constitutional" law,

${ }^{6}$ Allan T.R.S. (2011) Questions of legality and legitimacy: Form and substance in British constitutionalism. International Journal of Constitutional Law, vol. 9, Issue 1, pp. 155-162. URL: https://doi.org/10.1093/icon/mor017

7 Peters A. (2016) Legality as a Principle of Global Constitutional Law. European Convention on Human Rights and the Crimes of the Past. ECtHR Conference. URL: http://www.mpil.de/files/pdf4/Anne_Peters_Abstract_Legality_as_a_Principle_of_Global_Consti tutional_Law1.pdf 
which is higher than "ordinary" or "traditional" constitutional law. There are, under this approach, the two-level constitutional principles, in particular, the principle of legality. This peculiarity develops within the national legal system and is implemented to emphasize fundamentality and importance of such principles for the formation and development of the state.

Attention should also be paid to reviewing the constitutional principle of legality by the countries of the former socialist camp, since their understanding of this principle is close to Ukrainian and has similar historical background. For example, Romanian authors consider that the principle of legality is one of those constitutional principles that ensure the rule of law, along with the principle of separation of powers, the principle of protection of human rights and freedoms, the principle of equality of rights and responsibilities of all citizens, the principle of political diversity, the principle of free access to justice, the principle of the independence of the judiciary ${ }^{8}$.

The principle of legality requires all subjects of law, natural and legal persons, citizens and foreigners, public authorities, private organizations to comply with the law and other normative acts based on it, participating in any public relations. This state of affairs is guaranteed with court sanctions. Another understanding of the principle of legality is also offered by Romanian researchers: in addition to requiring all subjects of law to comply with legal rules he currently in force, the principle of legality also implies respect for the hierarchy of legal norms and their organization into a pyramid system ${ }^{9}$.

Bulgarian professor Tanchev Evgeni examines legality through the prism of a lack of legitimacy that is general characteristic of young democracy countries. He suggests that if the legal system is legitimate, then legality can become the best protective principle of a legitimate constitutional system, can ensure confidence in public authorities and support a democratic system ${ }^{10}$. It can be said that ensuring legitimacy in the activities of government institutions will help to reduce the low level of public trust in public authorities and local self-government.

Attention should be given to the difference between notions "constitutional legality" and "constitutional legitimacy". The main peculiarity

${ }^{8}$ Stoian A., Drăghici T. (2015) The principle of legality, principle of public law. Knowledgebased organization. International conference. Vol. XXI, No 2. P. 512-515.

${ }^{9}$ Stefannoaia M. The Role of the Constitutional Court of Romania in the Constitutionalization of Criminal Law. Drepturi și libertăți fundamentale: dimensiune istorică și constituțională - in memoriam prof. Univ. dr. Grigore Theodoru - 1919-2015. Conferința națională. URL: $\mathrm{http} / / /$ revista.universuljuridic.ro/supliment/role-constitutional-court-romania-

constitutionalization-criminal-law-2/

${ }^{10}$ Tanchev E. Constitutional safeguards of legality and legitimacy. Report to the Civil Service Forum at EIPA in Maastricht. Openness and Transparency in Governance: Challenges and Opportunities (NISPAcee 2000) / Ed. M. Kelly, P. 74. 
of constitutional legitimacy is that it is "a virtue rooted in a system of belief: the acceptance that an exercise in power is justified and therefore authorized, either implicitly or explicitly, by society at large". Moreover, it is stressed that "an illegal action may be legitimate in the eyes of the people, and conversely, simply because an action is legal does not always imply that it is legitimate" 11 . Taking into consideration that so called "young democracies", for instance, Ukraine, are characterized as countries with a lack of both legitimacy and legality and not developed civil society we strongly believe that constitutional legislation should involve the principle of constitutional legality as binding first of all supreme authorities of the state.

As for Ukrainian constitutional law science it can be noted that the study of legality was characterized as fragmented for a long time, its substantive characteristics were not revealed. The main reason for this state of affairs, in particular, was the analysis of this category in the system of socialist legality. At the same time it seems that there were some positive recommendations developed in early studies. For instance, putting the question of correlation between socialist and constitutional legality and determination the latter as basic category. The other recommendation is the proper implementation of laws by all bodies of state power, officials and citizens ${ }^{12}$. This meant recognizing public authorities as subjects whose activities (not only law enforcement) should be based on the principle of constitutional legality.

Attention is also should be drawn to distinguishing the principle of legality and the principle of constitutional legality as a main constituent of legality. The modern constitutional law science can be characterized by the lack of unity of scientific thought on aspects of constitutional legality. Although today the complex nature of this category and the scientific search for the main features that characterize its content are recognized. This complex approach fully corresponds to the experience of the democratic countries of Europe.

Several scientific views on the notion "constitutional legality" can be described. Firstly, constitutional legality considered to be a system of real existing law, which contemplates the existence of the constitution, its central role in the legal system of state, its direct application throughout the state, protection of its rules ${ }^{13}$, its correct application by authorities and officials ${ }^{14}$.

11 Chau, Brian (2012) Constitutional Legitimacy: An Analysis under Max Weber's Traditional Sources of Authority. URL: http://dx.doi.org/10.2139/ssrn.2192172

12 Problemy sotsialisticheskoy zakonnosti na sovremennom etape razvitiya sovetskogo gosudarstva: mezhvuz. nauch. konf. Tez. dokl. (okt. 1968 g.) / otv. red. M. I. Baru ; red. kol. V.A. Barakhtyan i dr. Khar'kov: Khar'k. yurid. in-t, 1968. p. 4 (in Russian).

${ }^{13}$ Krusjan A. (2012) Konstytucijna zakonnistj: pravova doktryna ta praktyka zabezpechennja i zakhystu v Ukrajini. Mytna sprava. № 1 (79). pp. 4-5. (in Ukrainian) 
Secondly it is considered as general requirement that reflects the necessity for the legitimate behavior or any activity of all subjects of constitutional legal relations ${ }^{15}$. Furthermore, some scientists call constitutional legality one of the methods of exercising state power, the essence of which is to create the necessary legislative acts, the mechanism of their implementation and appropriate control over their implementation by the state ${ }^{16}$. Others consider it as a special aspect of the concept of "legality", which demands compliance all of laws with the constitution of the country ${ }^{17}$. And lastly, the constitutional legality is considered as the type of legality, which is expressed in the legal nature of the constitution itself, its supremacy, the direct effect of the norms and principles of the constitution and in the institution of constitutional jurisdiction ${ }^{18}$.

To sum up it should be said that the constitutional legality has complex nature. This phenomenon covers various fields of state and public life, and therefore it can be considered as a principle, method and regime. Compliance with the constitution, laws, other legal acts, addressed to all bodies of state power and local self-government, officials, citizens and their associations, can be considered as its basic requirement. The constitutional legality covers not only implementation, application of legal rules, but also lawmaking, and that is why it is a complex category. The constitutional legality, in a static aspect, is the basis of the constitutional order of the country, it determines the legal nature of the activity of subjects of constitutional legal relations, and in the dynamic aspect it is a method and real manner of functioning of public authorities. This understanding allows us to evaluate both the product of rulemaking and the activity of the subjects of constitutional relations.

This peculiarity also allows to define such a feature of constitutional legality as the impact of its requirements, first of all, on the activities of public authorities. That is why the constitutional legality is often defined as a means of restriction of the power, which influence the effectiveness of the system of checks and balances. The legality in the state in general depends on the functioning of public authorities in the mode of constitutional legality.

${ }^{14}$ Jurydyčna encyklopedija: v 6 t. (2001) / redkol.: Ju. S. Šemčušenko. Kyjiv: "Ukr. encykl." T. 3: K-M. p. 288. (in Ukrainian)

${ }^{15}$ Tkachenko Ju. V. Konstytucijna zakonnistj jak pryncyp konstytucijnogho ladu. Forum prava. 2010. № 4. pp. 875-883. URL: http://nbuv.gov.ua/UJRN/FP_index.htm_2010_4_141 (in Ukrainian)

${ }^{16}$ Parxomenko N.M. (2012) Konstytucijna zakonnist' jak meta, vymoha ta pravovyj režym: teoretyčni aspekty. Al'manax prava. Vyp. 3. pp. 38-41. (in Ukrainian)

${ }^{17}$ Арутюнян Г.Г., Баглай М. В. Конституционное право: Энциклопедический словарь. Москва: Норма, 2006. С. 151.

${ }^{18}$ Skakun O. F. (2007) Teoryja hosudarstva y prava (эncyklopedyčeskyj kurs): učebnyk. Xar'kov: Эspada, 2007. pp. 711-712. (in Russian) 
Moreover, the process of civil society formation and functioning depends greatly on such a legal functioning. That is why the constitutional legality is one of important factor able to ensure civil society and to guarantee the rule of law.

Considering foreign practice one should said that in general it testifies to the wider use of the term "legality" - today it is incorporated in the Constitutions of more than one and a half hundred countries. For example, it was directly fixed in the Federal Constitutional Law of the Austrian Republic (Article 18, part 1): "The entire public administration shall be based on law"19; in Basic Law for the Federal Republic of Germany (Article 20, part 3): "The legislature shall be bound by the constitutional order, the executive and the judiciary by law and justice" 20 ; in Constitution of the Portuguese Republic (Article 3, part 2 "Sovereignty and legality"): "The state is subject to the Constitution and is based on democratic legality" ${ }^{21}$; in Constitution of Romania (Article 1, part 1): "In Romania, the observance of the Constitution, its supremacy and the laws shall be mandatory",22; in The Instrument of Government of Sweden (Article 1 chapter 1): "Public power is exercised under the law",23.

In Greece, the principle of legality is incorporated in a number of constitutional articles, which can be represented in the form of a requirement that the actions of the executive should comply with the norms of law at the level of the Constitution and laws ${ }^{24}$. Consequently, there is the emphasis on applying this principle to the actions of the executive branch. At the same time, in France, the principle of legality (French le principe de légalité) is not directly expressed in the text of the Constitution, but is applied as a general principle of law. There is the same approach to the application of the principle of legality (Dutch legaliteitsbeginsel) in the Netherlands.

\section{The means of ensuring the constitutional legality}

The constitutional legality considered to be a kind of "super-principle", which is crucial for all constitutional norms. It also corresponds to the "spirit"

19 Federal Constitutional Law of 10 November 1920. URL: https://www.ris.bka.gv.at/ Dokumente/Erv/ERV_1930_1/ERV_1930_1.pdf

${ }^{20}$ Basic Law for the Federal Republic of Germany. 23 May 1949. Last ammended on 12 July 2017. URL: https://www.btg-bestellservice.de/pdf/80201000.pdf

${ }^{21}$ Constitution of the Portuguese Republic of 21 August 1991. URL: http://www.en.parlamento.pt/ Legislation/CRP/Constitution7th.pdf

22 Constitution of Romania of 21 Novenber 1991. URL: http://www.cdep.ro/pls/ dic/site.page? $\mathrm{id}=371$

23 The Instrument of Government. URL: http://www.riksdagen.se/en/SysSiteAssets/07.dokument--lagar/the-instrument-of-government-2015.pdf/

${ }^{24}$ Brandhof J. C. E. van den. (2004) Constitutional Law of 15 EU Member States, Kluwer, P. 401. 
of the Basic Law of any democratic country and constitutional state, and therefore may not be expressed in text, which poses a serious threat of its violation by the authorities. As the German constitutionalist Ernst-Wolfgang Böckenförde remarked, constitutional legality is not created by itself, the practice of legality is based on political conditions which it cannot guarantee" 25 . Therefore, there should be specific constitutional institutions aimed at ensuring constitutional legality that will allow making a system of "principle - guaranteeing institution - regime". The absence of such institutions, special means as a response to violations of constitutional legality, will not let the latest to be a mode of functioning of public authority and will lead to the loss of value of the principle legality as a whole.

Judicial constitutional control is considered to be a traditional way of ensuring and protecting constitutional legality. Constitutional Court as a separate body is called the "watchdog of the Constitution in a given country, and as a protector of the constitutionality, legality, and the citizens' freedoms and rights within the national legal system" $"$.

The development of parliamentarism cause the need to control the activity of the legislator. However, the institution of constitutional control met with opposition, representing by parliamentary sovereignty as a foundation of parliamentarism. One of the consequences of the historical recognition of the sovereignty and supremacy of parliaments in European states was the prohibition of judicial review of parliamentary acts for constitutionality. Today, the so-called principle of "legislative supremacy" is criticized by researchers ${ }^{27}$.

The main reason against is inappropriateness of defining relations between branches of power in terms of rivalry and the superiority of one government body over another. However, the idea of prohibiting the judicial control over parliamentary acts, although not widespread, remains embodied in some countries. For example, according to Article 120 of the Constitution of the Kingdom of the Netherlands "The constitutionality of Acts of Parliament and treaties shall not be reviewed by the courts" 28 .

25 Böckenförde E-W. (1991) State, society, liberty: studies in political theory and constitutional law. New York: Berg. P. 171.

${ }^{26}$ Karakamisheva-Jovanovska T. (2010) Different Models for protection of constitutionality, legality and independence of constitutional court of the Republic of Macedonia. Venice Commission. URL: http://www.venice.coe.int/WCCJ/Rio/Papers/MKD_Karakamiseva_E.pdf

${ }^{27}$ Porter J. C. A. (2013) Constitutional review in the Netherlands: a joint responsibility. Utrecht Law Review. 9 (2), P. 89.

${ }^{28}$ The Constitution of the Kingdom of the Netherlands. URL: https://www.government.nl/ documents/regulations/2012/10/18/the-constitution-of-the-kingdom-of-the-netherlands-2008 
The influence of the principle of legislative supremacy is also clear in other parliamentary monarchies. The Constitutional Act of Denmark of $1953^{29}$ makes no mention of the right of courts to exercise constitutional control. In practice, such a power exists, however, governed by a constitutional custom based on the constitutional principle of separation of powers. This custom was formed as early as the 1920s, when the Supreme Court expressed a legal position on the possibility of judicial review of laws for compliance with the Constitution $^{30}$. Therefore, the present day constitutional control is exercised by courts of general jurisdiction, however, it is only a matter of reviewing the laws for compliance with the constitution, as well as observance procedural rules while adopting them.

Nearly the same situation concerns countries with a republican form of government, which, although institutionalized judicial constitutional control, but also restricted it by providing the power to check only parliamentary acts. For example, the Supreme Special Court of Greece court can only consider the constitutionality of laws, not acts of the executive branch (article 100 of the The Constitution of Greece ${ }^{31}$ ). In Romania, the question of the constitutionality of governmental acts is also impossible, because according to the Constitutional Court of Romania's judgment of 371 April 13, 2010, these acts can only be the subject of review of lawfulness in the order of administrative justice, because they are administrative by nature ${ }^{32}$. According to Article 149 of the Constitution of the Republic of Bulgaria, governmental acts may not be subject to judicial constitutional control also. However, acts of the Council of Ministers and Ministers may be declared illegal in the administrative procedure of the Supreme Administrative Court of Bulgaria (part 2, Article 125 of the Constitution ${ }^{33}$ ). As a result, the only means ensuring legality of the supreme executive body activities, but not a constitution legality directly, is the institution of administrative justice.

There is different trend in other EU countries, where a specialized body is given a considerable amount of authority within the framework of the Austrian model of constitutional control. Within this model a huge amount of

29 The Constitutional Act of Denmark. URL: http://www.thedanishparliament.dk/ Publications/The_Constitutional_Act_of_Denmark.aspx

${ }^{30}$ Isaev M. A. Mekhanizm gosudarstvennoy vlasti v stranakh Skandinavii. Konstitutsionnopravovye aspekty: dis. ... d-ra yurid. nauk. Moskva, 2004. 371 s. (in Russian)

31 The Constitution of Greece. URL: http://www.hellenicparliament.gr/UserFiles/f3c70a237696-49db-9148-f24dce6a27c8/001-156\%20aggliko.pdf

${ }^{32}$ Rule of law, human rights and judicial control of power (2017) / ed. Rainer A., MartinezEstay J. I. 1-st ed. Springer. 446 pp. 35-36.

${ }_{33}$ Constitution of the Republic of Bulgaria. URL: https://www.wipo.int/edocs/lexdocs/ laws/en/bg/bg033en.pdf 
EU member States establish the review of not only parliamentary, but also of governmental acts (for instance, Article 102 of the Constitution of the Republic of Lithuania ${ }^{34}$, Article 125 of Constitution of the Slovak Republic ${ }^{35}$ ). One more group of countries established review for constitutionality of all acts of public authorities regardless of the branch of power (for instance, Article 188 of the Constitution of the Republic of Poland ${ }^{36}$, Article 153 of Constitution of the Republic of Slovenia ${ }^{37}$, Article 125 of Constitution of the Republic of Croatia $^{38}$ ).

The extension of the Constitutional Tribunal of the Republic of Poland powers caused by constitutional provision on the possibility of reviewing the conformity of the constitution, ratified international treaties and the laws of the act of any central body of the state (Article 188 of the Constitution ${ }^{39}$ ). The extensive powers of the Constitutional Tribunal in the field of reviewing the constitutionality and legality of regulatory acts are nevertheless balanced by the inability of the Constitutional Tribunal to initiate such reviews at its own discretion.

As a conclusion it should be mentioned that principle of parliamentary sovereignty, which has historically come with the change of absolute monarchies in Europe, still has a significant impact on the development of constitutional justice. For instance, there is prohibition on constitutional control in general in some countries. Nevertheless, due to the development of public relations, the restriction of parliamentary sovereignty and judicial constitutional control is becoming necessary to state-making processes. However, it should be also noted that the issue of control over governmental acts owing to the need to find a balance between the legislative and judicial branches of power in this case is too early to raise in the individual states. It is stated that control of legality of the governmental act is sufficient. Although the significance of executive branch of power is doubtless.

${ }^{34}$ The Constitution of the Republic of Lithuania. URL: http://www3.1rs.lt/home/Konstitucija/ Constitution.htm

35 Constitution of the Slovak Republic of 1 September 1992. URL: https://www.prezident.sk/upload-files/46422.pdf

${ }^{36}$ The Constitution of the Republic of Poland. Dziennik Ustaw No. 78, item 483. URL: http://www.sejm.gov.pl/prawo/konst/angielski/kon1.htm

37 Constitution of the Republic of Slovenia of 23 December 1991. Official Gazette of the Republic of Slovenia Nos. 33/91-I, 42/97, 66/2000, 24/03, 69/04, 68/06, and 47/13. URL: https://www.dz-rs.si/wps/portal/en/Home/PoliticniSistem/UstavaRepublikeSlovenije

38 Constitution of the Republic of Croatia NN 85/2010, 09.07.2010. URL: https://www.wipo.int/edocs/lexdocs/laws/en/hr/hr060en.pdf

${ }^{39}$ The Constitution of the Republic of Poland. Dziennik Ustaw No. 78, item 483. URL: http://www.sejm.gov.pl/prawo/konst/angielski/kon1.htm 
In the modern world the role of the highest executive authorities is increasing. According to the Jean Blondel "The executive is manifestly a focal point, if not the focal point of political life. This remains true even if doubts are sometimes expressed about the ability of executives to affect markedly the course of events, let alone alter drastically the social and economic structure of their country. At least they have, more than any other body, an opportunity to shape society; it is indeed their function to do so" $"$. The supreme body of the executive power determines the directions of policy within "the framework set by the legislation enacted by parliament, and is at the head of the administrative apparatus of the

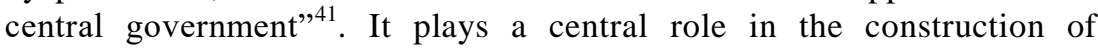
national economy, contribute to police-making at national, regional and international levels, etc. The role of governments may be exemplified by the expression: "government refers to the body or bodies responsible for governing the State"42 that is also laid down at the constitutional level (for instance, in article 6 Chapter 1 of the Instrument of Government of Sweden: "The Government governs the Realm"43).

As a consequence there should be another means how to protect legality of executive branch of power. One more institution considered to be an effective means of ensuring legality of the public authority is constitutional liability.

Ensuring the balance of state power with the guarantee of democratic foundations of the political system and the regime of constitutional legality make the special attention to the issues of the effectiveness of the institution of the constitutional liability of the government. Being an important element in the system of checks and balances, this institute is in the field of dynamic political and legal relations, increasingly demonstrating its flexibility and adaptability. The complex constitutional modernization, initiated in Ukraine in the context of obvious intensification the European integration processes, actualizes the improvement of the existing and development of new mechanisms of constitutional liability on the basis of a modern doctrinal basis. Moreover, such mechanism should take into consideration the latest achievements and tendencies of development of the governmental liability institution.

\footnotetext{
${ }^{40}$ Encyclopedia of Government and Politics (1992) / Ed. by M. Hawkesworth and M. Kogan. London, New York. P. 267.

${ }^{41}$ Brandhof J.C.E. van den. (2004) Constitutional Law of 15 EU Member States, Kluwer, P. 512.

42 The Machinery of Government. Structure and functions of Government. May 2003, Department of Public service and Administration. URL: http://www.dpsa.gov.za/dpsa2g/ documents $/ \mathrm{lkm} / \mathrm{mog}$.pdf

43 The Instrument of Government. URL: http://www.riksdagen.se/en/SysSiteAssets/07.dokument--lagar/the-instrument-of-government-2015.pdf/
} 
Constitutional liability can be characterized as defined by the constitution of the state, guaranteed by state sanctions the constitutional obligation of the highest executive authorityи for the proper performance of its constitutional functions and duties, as well as the condemnation and coercive influence in case of improper performance of such functions and duties, as well as in the case of resolving constitutional conflicts.

The main purpose of constitutional liability is to protect the constitution and the regime of constitutional legality. The importance of the constitutional liability of the government for ensuring constitutional legality was outlined by Polish professors Wojciech Sokolewicz and Sabina Grabowska: firstly, this institution ensures observe of the constitution by officials who perform the most important functions in the state. This means not only abstaining from violating constitutional provisions, but also committing actions aimed at implementing constitutional norms. Secondly, it guarantees that the subjects of constitutional liability includes the principles of legality and the rule of law in their activities ${ }^{44}$.

There are different forms of governmental liability. Firstly, collective and individual forms, which differs according to the subject. Secondly, parliamentary liability (the collective liability of the government and the individual liability of the prime minister and / or ministers), liability to the head of state, to a specially created or constitutional court. The instance of such liability may be represented by the Parliament, the Head of State and a specially created or constitutional court.

The transformation processes of constitutional liability of the government institution have affected the role of the instances of liability in European states, in particular, of the head of state. His significance is more of an exception than a general rule. For instance the head of state is not independent and acts in a certain "tandem" with the prime minister in the mechanism of individual liability of ministers in Germany. According to Part 1 of Art. 64 of the Basic Law of Germany "Federal ministers are appointed and dismissed by the Federal President at the proposal of the Federal Chancellor"45. The federal president is obliged to appoint and dismiss a person proposed by the Federal Chancellor, the proposals of the latter are beyond doubt ${ }^{46}$. This rule exist due to the "Chancellor principle" (German Kanzlerprinzip).

${ }^{44}$ Sokolewicz W. Art. 156. (2007) Konstytucja Rzeczypospolitej Polskiej. Komentarz. Volume Second / Ed. L. Garlicki. Warszawa: Wydawnictwo Sejmowe, pp. 2-3.

${ }^{45}$ Basic Law for the Federal Republic of Germany. 23 May 1949. Last ammended on 12 July 2017. URL: https://www.btg-bestellservice.de/pdf/80201000.pdf

${ }^{46}$ Fisher J., Kaiser A. (2011) Wie gewonnen, so zerronnen? Selektions- und Deselektionsmechanismen in den Karrieren deutscher Bundesminister. Politische Vierteljahresschrift Sonderheft. Sonderheft 44/2010, "Politik als Beruf". S. 195-196. 
Moreover, since the control powers often are not used by the head of state. For instance, the Federal President of Austria theoretically can dismiss the Federal Chancellor or the Federal government on his own, but in practice he does not use this power according to so called "renunciation of role" (German "Rollenverzicht"). It means the refusal to take an active part in daily politics, use discretional powers, especially in matters of appointment and dismissal of chancellors and ministers. Therefore, the institution of constitutional liability, its forms and realization is a case of major importance for modern European countries.

\section{CONCLUSIONS}

Summing up, the following references can be made. Today formation and active development of civil society as a system of social institutions (state, family, local self-government, public, religious organizations, political parties, the media etc.), as well as relations between them (political, economic, social, cultural etc.), undoubtedly, takes place. Therefore, it is also necessary to pay attention to the role of state authorities in this process. Since the main aim of civil society is to ensure the rights and freedoms of man and citizen, it is necessary to create certain restrictive institutions for the purpose to ensure state authority functioning in accordance with the principle of constitutional legality.

The notion of "legality" is one of the most important in the constitutional doctrine and constitutional legislation of European countries. Legality is the most important component of the rule of law as a key idea of the functioning of the state and society. Given the obvious importance of this notion, the question of appropriate means aimed at ensuring and guaranteeing the rule of law in a modern state arises. This issue is especially important for the countries of young democracy, where the legal culture of citizens as well as officials does not reach a high level.

The traditional means of ensuring constitutional legality is constitutional review or control. However, due to historical reasons, this institution is not always able to respond to illegal or unconstitutional actions of the executive branch of state power. Therefore, the functioning of the institution of constitutional liability of the government becomes important. This institution through various forms and instances can provide control and enforcement of government actions in accordance with the law.

\section{SUMMARY}

The paper looks at researches dealing with the problem of the principle of legality and its main part - constitutional legality. Various views of European, American and Ukrainian of the experts in the field of constitutional law on the notion of legality are considered. Much attention is given to the interpretation of the principle of legality considered in 
British doctrine. It is also established that constitutional legality is a complex category covering not only implementation, application of legal rules, but also lawmaking.

The paper also gives valuable information on the constitutional and legal regulation of the principle legality. Besides, the paper is concerned with the means of ensuring constitutional legality, such as constitutional control and constitutional liability. It is stressed that constitutional liability of bodies of state power can be an effective measure, especially taking into consideration that many countries establish the possibility to oversight only legality of governmental statutory acts. The general description of the constitutional liability is given. Protection of constitution and regime of constitutional legality is defined as a main purpose of constitutional liability.

\section{REFERENCES}

1. Allan T.R.S. (2011) Questions of legality and legitimacy: Form and substance in British constitutionalism. International Journal of Constitutional Law, vol. 9, Issue 1, pp. 155-162. URL: https://doi.org/10.1093/icon/mor017

2. Basic Law for the Federal Republic of Germany. 23 May 1949. Last ammended on 12 July 2017. URL: https://www.btg-bestellservice.de/ pdf/80201000.pdf

3. Böckenförde E-W. (1991) State, society, liberty: studies in political theory and constitutional law. New York: Berg. 272 p.

4. Brandhof J.C.E. van den. (2004) Constitutional Law of 15 EU Member States, Kluwer, 949 p.

5. Chau, Brian (2012) Constitutional Legitimacy: An Analysis under Max Weber's Traditional Sources of Authority. URL: http://dx.doi.org/10.2139/ ssrn. 2192172

6. Constitution of Romania of 21 November 1991. URL: http://www.cdep.ro/pls/dic/site.page?id=371

7. Constitution of the Portuguese Republic of 21 August 1991. URL: http://www.en.parlamento.pt/Legislation/CRP/Constitution7th.pdf

8. Constitution of The Republic of Bulgaria. URL: https://www.wipo.int/ edocs/lexdocs/laws/en/bg/bg033en.pdf

9. Constitution of the Republic of Croatia NN 85/2010, 09.07.2010. URL: https://www.wipo.int/edocs/lexdocs/laws/en/hr/hr060en.pdf

10. Constitution of the Republic of Slovenia of 23 December 1991. Official Gazette of the Republic of Slovenia Nos. 33/91-I, 42/97, 66/2000, 24/03, 69/04, 68/06, and 47/13. URL: https://www.dz-rs.si/wps/portal/en/ Home/PoliticniSistem/UstavaRepublikeSlovenije

11. Constitution of the Slovak Republic of 1 September 1992. URL: https://www.prezident.sk/upload-files/46422.pdf 
12. Encyclopedia of Government and Politics (1992) / Ed. by M. Hawkesworth and M. Kogan. London, New York. 637 p.

13. Federal Constitutional Law of 10 November 1920. URL: https://www.ris.bka.gv.at/Dokumente/Erv/ERV_1930_1/ERV_1930_1.pdf

14. Fisher J., Kaiser A. (2011) Wie gewonnen, so zerronnen? Selektionsund Deselektionsmechanismen in den Karrieren deutscher Bundesminister. Politische Vierteljahresschrift Sonderheft. Sonderheft 44/2010, "Politik als Beruf". S. 192-212.

15. Isaev M.A. Mekhanizm gosudarstvennoy vlasti v stranakh Skandinavii. Konstitutsionno-pravovye aspekty: dis. ... d-ra yurid. nauk. Moskva, 2004. 371 s. (in Russian)

16. Jurydyčna encyklopedija: v 6 t. (2001) / redkol.: Ju. S. Šemčušenko. Kyjiv: “Ukr. encykl”. T. 3: K-M. pp 610. (in Ukrainian)

17. Karakamisheva-Jovanovska T. (2010) Different Models for protection of constitutionality, legality and independence of constitutional court of the Republic of Macedonia. Venice Commission. URL: http://www.venice.coe.int/WCCJ/Rio/Papers/MKD_Karakamiseva_E.pdf

18. Krusjan A. (2012) Konstytucijna zakonnistj: pravova doktryna ta praktyka zabezpechennja i zakhystu v Ukrajini. Mytna sprava. № 1 (79). pp. 4-5. (in Ukrainian)

19. Lim B. (2013) The Normativity of the Principle of Legality. Melbourne University Law Review, Vol. 37:372. pp. 372-414.

20. Parxomenko N.M. (2012) Konstytucijna zakonnist' jak meta, vymoha ta pravovyj režym: teoretyčni aspekty. Al'manax prava. Vyp. 3. pp. 38-41. (in Ukrainian)

21. Peters A. (2016) Legality as a Principle of Global Constitutional Law. European Convention on Human Rights and the Crimes of the Past. ECtHR Conference. URL: http://www.mpil.de/files/pdf4/Anne_Peters_Abstract_ Legality_as_a_Principle_of_Global_Constitutional_Law1.pdf

22. Porter J.C.A. (2013) Constitutional review in the Netherlands: a joint responsibility. Utrecht Law Review. 9 (2), pp. 89-105.

23. Problemy sotsialisticheskoy zakonnosti na sovremennom etape razvitiya sovetskogo gosudarstva: mezhvuz. nauch. konf. Tez. dokl. (okt. 1968 g.) / otv. red. M.I. Baru ; red. kol. V.A. Barakhtyan i dr. Khar'kov: Khar'k. yurid. in-t, 1968. 291 p. (in Russian)

24. Rule of law, human rights and judicial control of power (2017) / ed. Rainer A., Martinez-Estay J.I. 1-st ed. Springer. 446 p.

25. Sales P. (2008) A comparison of the principle of legality and section 3 of the Human Rights Act 1998. Statute law society conference. Belfast. URL: http://www.statutelawsociety.co.uk/wp-content/uploads/2014/01/A_ 
comparison_of_the_principle_of_legality_and_section_3_of_the_Human_Rig hts_Act_1998._Mr_Justice_Sales.pdf

26. Skakun O.F. (2007) Teoryja hosudarstva y prava (эncyklopedyčeskyj kurs): učebnyk. Xar'kov: Эspada, 2007. 840 p. (in Russian)

27. Sokolewicz W. Art. 156. (2007) Konstytucja Rzeczypospolitej Polskiej. Komentarz. Volume Second / Ed.L. Garlicki. Warszawa: Wydawnictwo Sejmowe, pp. 1-32.

28. Stefannoaia M. The Role of the Constitutional Court of Romania in the Constitutionalization of Criminal Law. Drepturi și libertăți fundamentale: dimensiune istorică și constituțională - in memoriam prof. Univ. dr. Grigore Theodoru - 1919-2015. Conferința națională. URL: $\mathrm{http} / / /$ revista.universuljuridic.ro/supliment/role-constitutional-court-romaniaconstitutionalization-criminal-law-2/

29. Stoian A., Drăghici T. (2015) The principle of legality, principle of public law. Knowledge-based organization. International conference. Vol. XXI, No 2. P. 512-515.

30. Sunstein C. R. (2005) Radicals in Robes: why extreme right-wing courts are wrong for America, New York: Basic Books, XV, 281 pp.

31. Tanchev E. Constitutional safeguards of legality and legitimacy. Report to the Civil Service Forum at EIPA in Maastricht. Openness and Transparency in Governance: Challenges and Opportunities (NISPAcee 2000) / Ed. M. Kelly. pp. 72-99.

32. The Constitution of Greece. URL: http://www.hellenicparliament.gr/ UserFiles/f3c70a23-7696-49db-9148-f24dce6a27c8/001-156\%20aggliko.pdf

33. The Constitution of the Kingdom of the Netherlands. URL: https://www.government.nl/documents/regulations/2012/10/18/the-

constitution-of-the-kingdom-of-the-netherlands-2008

34. The Constitution of the Republic of Lithuania. URL: http://www3.lrs.lt/home/Konstitucija/Constitution.htm

35. The Constitution of the Republic of Poland. Dziennik Ustaw No. 78, item 483. URL: http://www.sejm.gov.pl/prawo/konst/angielski/kon1.htm

36. The Constitutional Act of Denmark. URL: http://www.thedanishparliament.dk/Publications/The_Constitutional_Act_of_ Denmark.aspx

37. The Government and the Principle of Legality. URL: https://www.lawteacher.net/free-law-essays/administrative-law/thegovernment-and-the-principle-of-legality-administrative-law-essay.php\#ftn9

38. The Instrument of Government. URL: http://www.riksdagen.se/en/ SysSiteAssets/07.-dokument--lagar/the-instrument-of-government-2015.pdf/ 
39. Tkachenko Ju. V. Konstytucijna zakonnistj jak pryncyp konstytucijnogho ladu. Forum prava. 2010. № 4. pp. 875-883. URL: http://nbuv.gov.ua/UJRN/FP_index.htm_2010_4_141 (in Ukrainian)

\section{Information about the author:}

Alina Murtishcheva,

Candidate of Legal Sciences, Assistant Lecturer at the Department of State Construction, Yaroslav Mudryi National Law University 77, Pushkinskaya str., Kharkiv, 61024, Ukraine ORCID ID: orcid.org/0000-0001-6520-7297 